\title{
EM BUSCA DA GEOGRAFIA PERDIDA: POÉTICA, NARRATIVA E PAISAGEM EM MARCEL PROUST ${ }^{1}$
}

\author{
EN BUSCA DE LA GEOGRAFÍA PERDIDA: POÉTICA, NARRATIVA Y \\ PAISAJE EN MARCEL PROUST
}

\section{IN SEARCH OF LOST GEOGRAPHY: POETIC, NARRATIVE AND LANDSCAPE IN MARCEL PROUST}

\author{
Cláudio Benito O. Ferraz ${ }^{2}$ \\ Universidade Estadual Paulista “Júlio de Mesquita Filho" (UNESP), Presidente \\ Prudente, Brasil
}

Resumo: Este artigo objetiva estabelecer alguns apontamentos sobre a obra de Marcel Proust, principalmente o seu clássico Em Busca do Tempo Perdido, em direção a outros sentidos para a linguagem geográfica, notadamente a partir do mergulho no cotidiano, os detalhes das coisas, sentimentos e fenômenos que acontecem nos diversos lugares em que a vida humana se territorializa.

Palavras-chave: Proust; Verdade; Paisagem.

Abstract: This article aims to establish some notes about the work of Marcel Proust, especially his classic In Search of Lost Time (À la recherche du temps perdu), toward other meanings for the geographic language, especially from the dip in daily life, the details of things, feelings and phenomenas that occur in most places where human life is territorialize.

Keywords: Proust; Truth; Landscape.

Resumen: Este trabajo tiene como objetivo establecer algunas notas sobre la obra de Marcel Proust, sobre todo su clásico En busca del tiempo perdido hacia otros significados de la lengua geográfica, especialmente de la caída en el diario, los detalles de las cosas, sentimientos, y los fenómenos que ocurren en muchos lugares donde la vida humana sucede.

Palabras clave: Proust; la Verdad; Paisaje.

\section{INTRODUÇÃO: UMA GEOGRAFIA PERDIDA A SER BUSCADA}

\footnotetext{
${ }^{1}$ Este texto é o desdobrar das atividades de pesquisas desenvolvidas no interior do Grupo de Pesquisa Linguagens Geográficas e integra Projeto Imagens, Geografias e Educação - Processo CNPq 477376/2011-8. Foi elaborado especialmente para coordenação da Mesa Redonda ESTÉTICA, POÉTICA E NARRATIVA: ENTRE FLUIDEZ E PERMANÊNCIAS NAS ARTES, que ocorre no interior do II Simpósio Nacional de Geografia, Literatura e Arte e I Simpósio Internacional de Geografia, Literatura e Arte.

${ }^{2}$ Professor Doutor em Geografia do Departamento de Educação da FCT/UNESP de Presidente Prudente (SP). Coordenador do Grupo de Pesquisa Linguagens Geográficas. Membro da Rede Imagens, Geografias e Educação. E-mail: cbenito2@yahoo.com.br.
} 
Em Busca do Tempo Perdido é livro único. Suas personagens são enigmáticas e complexas, assim como o narrador das várias histórias que se cruzam ou se desprendem, o qual só duas vezes ao longo da obra é denominado como Marcel. O universo dos sete volumes [No Caminho de Swann (1992); À Sombra das Moças em Flor (1993a); O Caminho de Guermantes (1993b); Sodoma e Gomorra (1994a); A Prisioneira (1994b); A Fugitiva (1995a); Tempo Recuperado (1995b)] que compõe esse monumento de sensações expressa um grande mosaico de dilemas pessoais, conflitos psicológicos, crises políticas nacionais, amores não correspondidos, ciúmes doentios, indefinições sexuais e profissionais, dilemas estéticos e filosóficos, paradoxos morais e éticos, assim como o inexorável processo de envelhecimento à custa da percepção do tempo que a tudo corrói e transforma.

A quase totalidade dos pesquisadores de sua obra, assim como os críticos literários, entende ser esse um romance que visa dar forma aos sentidos do tempo e da memória, esta última tomada como a única força capaz de perdurar no corpo do ser humano um pouco do passado vivenciado ou imaginado. Fernando Py, em apresentação da sua tradução do gigantesco romance de Proust, assim nos esclarece.

Os principais temas de Em Busca do Tempo Perdido são o Tempo e a Memória. Proust era um obcecado pelas questões relativas ao tempo. Preocupava-o o passar dos anos que leva tudo de arrasto, modificando, transformando, vencendo e extinguindo todos os sentimentos, paixões, amores, ideias, opiniões e até os corpos. Com o passar do tempo, o esquecimento e a indiferença sobem das profundezas do indivíduo para destruir tudo aquilo que o ser humano julgara eterno e inamovível. Nem mesmo aquele núcleo invariável do espírito, que a filosofia clássica acreditava formar a nossa personalidade, resiste à ação do tempo (in PROUST, 1992, p. 10).

No entanto, apesar de concordarmos com a importância dada ao sentido, ou sentidos, da temporalidade em sua obra, basta ver o título da mesma, queremos aqui destacar o elemento espacial como processo inerente ao desdobrar temporal apresentado no referido livro. Para tal, façamos uso dos estudos desenvolvidos por George Poulet (1992) sobre o espaço na obra de Proust.

É curioso que aquele que tantas vezes se quis fazer um discípulo de Bergson tenha assumido, provavelmente sem o saber, uma posição diametralmente contrária. Se o pensamento de Bergson denuncia e rejeita a metamorfose do tempo em espaço, Proust não somente a ela se acomada mas nela se instala, levando-a ao extremo, tornando-a, enfim, um dos princípios de sua arte [...]. À má justaposição, ao espaço intelectual condenado por Bergson, opõe-se uma boa justaposição, um espaço estético, onde, ordenando-se, os momentos e 
os lugares formam a obra de arte, conjunto rememorável e admirável (POULET, 1992, p. 11).

Poulet destaca a imbricada relação no romance proustiano entre o tempo e o espaço, no caso em questão, qualificado como elemento estético, o qual, para o que aqui nos interessa, assume ser um intercessor de grande força à potência que o mesmo pode tomar em sua perspectiva geográfica. Explicando melhor, percebemos na obra de Proust que o fator espaço, em sua abordagem estética, se territorializa em perceptos que derivam em conceitos a partir dos lugares nos quais as experiências, a serem rememoradas, ocorreram. O romance é uma busca pela localização do sentido de uma vida no tempo e nos lugares em que a mesma territorializou sua existência. $\mathrm{O}$ início famoso do primeiro livro é justamente o despertar insone do personagem central, o narrador, que começa a pensar sobre sua vida e de como se encontra desorientado no seu quarto, mas este é apenas o lugar em que o espaço do mundo por ele vivenciado se manifesta, articulando, num jogo de escalas temporais e espaciais, outros lugares e situações.

A verdade é que, quando eu assim acordava, meu espírito agitando-se para tentar saber, sem o conseguir, onde me encontrava, tudo girava ao meu redor no escuro, as coisas, os países, os anos. Meu corpo, entorpecido demais para se mexer, buscava, segundo a forma do seu cansaço, localizar a posição dos membros para daí deduzir a direção da parede, a situação dos móveis, para reconstruir e denominar a moradia em que se achava (PROUST, 1992, p. 23. Destaques nosso).

Ao despertar, o narrador encontra-se desorientado, não sabe onde e quando está. Mas seu corpo, mais que sua mente, instiga a resgatar memórias de outros lugares e ambientes, outros quartos nos quais se locomoveu e experimentou, instaurando em seu pensar referenciais que permite se entender. Incialmente estabelece a distribuição e apreensão das superfícies espaciais das partes de seu corpo biológico, permitindo territorializar em seu ser as formas paisagísticas com as quais reconhece sua espacialidade própria, corporal.

Em decorrência, e conjuntamente a isso, vai agenciando a interação de seu corpo com o ambiente imediato por meio do rememorar de outras experiências corporais ocorridas em outros lugares, permitindo à memória configurar as formas das coisas e suas localizações no lugar atual frente aos demais lugares relembrados. A partir desse processo inicial, sua consciência se abre para o conjunto espacial do mundo por ele vivenciado, articulando parâmetros pertinentes para um despertar no e pelo qual seu ser 
tenha condições de se orientar e se localizar frente as demais coisas, países e anos. Diante dessa situação, Poulet conclui.

"Tentando descobrir onde estava..." Vê-se claramente que desde o primeiro momento - quase que se poderia dizer: desde o primeiro lugar - da narrativa, a obra proustiana se afirma como uma busca não somente do tempo, mas também do espaço perdido (POULET, 1992, p. 17).

A perda do tempo é o esgaçar da memória dos lugares e situações vivenciadas neles. Eis o aspecto mais emblemático e ao mesmo tempo pueril que Proust coloca em sua obra. Perdemos a noção de espaço ao nos perdermos de nós mesmos. Saber quem somos é saber para onde queremos ir; para tal, torna-se necessário localizarmos no aqui e agora, mas essa possibilidade se encontra relacionada com nossa memória de outros momentos e lugares vivenciados e/ou imaginados. O livro de Proust é exatamente essa busca por um tempo e espaço perdidos; o narrador vai apresentando todo o desenrolar cotidiano e minucioso dessa redescoberta do ser num mundo cada vez mais complexo, fragmentado, dinâmico e volátil.

Desta feita, o livro não busca só um tempo como resgate de uma história perdida, mas através de seus vários personagens e situações, apresenta um sentido de geografia que foi perdida em prol da substituição rápida das coisas nos lugares, assim como a própria transformação dos lugares por meio de novos usos e sentidos neles criados, produzindo novas paisagens e significados, desterritorializando as lembranças e incapacitando os homens de regionalizarem seus processos identitários por meio dos referenciais até então exercitados.

O artigo aqui visa contribuir exatamente nessa direção, qual seja, destacar alguns elementos dessa geografia perdida enquanto território da memória, como forma de buscar os elementos fundantes do sentido de viver humano no mundo, ou seja, recriar os sentidos dos lugares enquanto espacialização da vida. Isso não significa, como o próprio romance de Marcel Proust brilhantemente anuncia, voltar a um passado, pois esse na verdade é produto do imaginário humano a partir do momento em que o rememora, pois olhar o passado é redescobrir sentidos até então não percebidos para se poder melhor se localizar no hoje, no aqui e agora em que a vida simplesmente acontece.

Portanto, buscar uma geografia perdida não é trazer de volta um conhecimento científico do passado, mas perscrutar nas experiências espaciais já vivenciadas os elementos que permitam estabelecer novas potências de sentidos de orientação e localização para os homens na atualidade. 
Já na estrutura de seu livro encontra-se o forte apego à geografia, pois a referência aos lugares de sua vida, aos nomes com os quais descobria o acesso aos mesmos, vai demarcar todo o processo de desenvolvimento do personagem central, que sempre recorda das pessoas e dos lugares de sua vida como forma de dar sentido à questão da memória que o tempo apaga e que volta a ser redescoberta.

De sua infância, em Combray, partiam-se dois caminhos, um lado rumava para a casa de Swann, representante da burguesia, o outro para os Guermantes, família aristocrática. Entre esses dois lugares desenvolve-se o romance que tem como pano de fundo a vida francesa do final do século XIX e início do século XX (Como o caso Dreyfus que foi várias vezes citado ao longo do romance além da incorporação de novas tecnologias, como é o caso do telefone a partir do qual o autor reflete sobre a subversão do espaço e do tempo na sociedade industrial e urbana), mas que prioriza a memória e o tempo no processo de amadurecimento e velhice das pessoas a partir dos lugares por elas habitados e experimentados, seja em imaginação seja em ato.

Como o romance é muito amplo e complexo, teremos aqui que fazer um corte e destacaremos alguns poucos aspectos na direção de nossos objetivos, notadamente na abordagem da questão da verdade e da paisagem, tanto para o discurso científico em geral, quanto na especificidade do conceito trabalhado pelo discurso geográfico. Sabemos que o livro de Marcel Proust não foi pensado como um texto geográfico por excelência, mas sim um bloco de sensações enquanto texto artístico. Para viabilizar as ideias pertinentes em seu interior com os referenciais geográficos por nós buscados, torna-se necessário estabelecer alguns intercessores capazes de nos ajudar nessa direção. É isso que propomos fazer nos próximos subitens desse artigo, no final apenas estamos exercitando uma possibilidade de sensibilizar no leitor a pertinência de ler Proust como grande auxílio para os estudos geográficos.

\section{A GEOGRAFIA DA VIDA COMO OBRA DE ARTE: NÃO EXISTE DUALIDADES SIMPLISTAS}

O volume IV de Em Busca do Tempo Perdido, Sodoma e Gomorra, aborda o amadurecimento sexual do personagem principal e seu contato com a prática homossexual entre homens e mulheres. É interessante que Proust coloca seu personagem deixando de ser criança via o primeiro contato com o amor, inicialmente com a pureza do amor de uma criança por outra, como foi o caso de Gilberte, e depois com a introdução da sexualidade, como no caso de Albertine. A partir de então o amor 
vai perdendo sua fantasia e se inter-relaciona com mentiras, ciúmes, dubiedades, assim como da necessidade de tomada de decisões por parte dos apaixonados; tais elementos passam a compor uma região até então não percebida para o narrador quando ainda criança, essa percepção acarretará consequências que até então, o homem enquanto menino não estava preparado para arcar e nem tinha consciência de que viver é assim. Ao tentar buscar ajuda com sua mãe, ela deixa em suas mãos a decisão.

Mas, com essas palavras, que colocavam nas minhas mãos a decisão sobre a minha própria felicidade, minha mãe me pusera nesse estado de dúvida em que eu já nem vira quando, tendo meu pai permitido que eu fosse à representação da Fedra, e principalmente, que me tornasse escritor, sentira de súbito uma responsabilidade excessivamente grande, o medo de afligi-lo, e aquela melancolia que se sente quando se deixa de obedecer a ordens que, no dia a dia, nos ocultam o futuro, de perceber que afinal começamos a viver a vida de verdade, como gente grande, a única vida que está à disposição de todos nós (1994, p. 273).

Essa questão é central em seu romance, desde o primeiro volume até o sétimo e último irá desenvolvendo e aprimorando o sentido da memória para o processo criativo e do entendimento da estreita relação entre vida e arte. Partindo de Bergson, Proust define a memória em dois níveis, as conscientes e voluntárias, fruto da reflexão objetivada; e as inconscientes e involuntárias, que resgatam aspectos que estavam aparentemente esquecidos e amortecidos no subconsciente humano. As segundas são mais ricas e profundas, pois carregam em si toda a intricada relação de sensações, ideias, intuições fantasias, experiências, imaginação, desejos e frustrações que cada ser humano produz e carrega dentro de si. Essa memória é que potencializa a relação espaço e tempo, resgatando lugares, pessoas, objetos e nomes experimentados em outro tempo, para o tempo agora, permitindo que o tempo, que a tudo destrói, possa ser recriado pelo homem, fazendo da vida uma obra de arte elaborada por cada um nós. Numa carta a René Blum, que consta do artigo Por uma Estética do Dia-a-Dia, escrito por Yves Sandre, encontra-se a seguinte explicação de Proust quanto à questão da memória:

Escolhi um título geral: À la Recherche du Temps Perdu [...]. É um título extremamente real mas aceitável porque imita de alguma forma a memória involuntária (que, no meu entender, ainda que Bergson não faça essa distinção, é a única verdadeira, já que a memória voluntária, a memória da inteligência e dos olhos só nos dá do passado facsímiles inexatos que não se parecem com ele como os quadros ruins dos pintores não retratam a primavera, etc...) (Apud SANDRE, 1971, p. 79-80). 
Proust descobre isso não só por meio de uma profunda análise filosófica ou científica do que vem a ser a vida, mas, consciente de sua grande bagagem teórica - e só por ter essa bagagem é que conseguiu qualificar a banalidade do gesto que impulsionou sua própria existência em busca de sentidos mais belos --, derivou dessa teorização os elementos estéticos e afetivos que o propiciaram perceber o sentido de sua existência no mundo a partir do acaso de um ato trivial; foi sua percepção artística ao observar os detalhes aparentemente insignificantes que compõem a espacialidade da vida, sendo esses territorializados e corporificados em imagens e nomes que ficam ocultos em nossas memórias, conscientes e inconscientes, e acabam, por fatores aleatórios e contingenciais, se presentificando em outras situações que os resgatam, e assim delimitam a capacidade humana de elaborar os sentidos passíveis de amenizarem nossas angústias e necessidades.

A cena em que narra este desvendar, já tantas vezes referenciada, consta de um gesto que, respeitando a especificidade do personagem em questão, foi experimentada por todos nós em determinados momentos de nossa existência; é a cena em que o narrador mergulha uma "madeleine”, um biscoito, numa xícara de chá e tal ato, junto com o aroma e o com o sabor, trouxe recordações de outro momento de sua vida, de outro espaço e tempo habitado por ele.

Fazia já muitos anos que, de Combray, tudo que não fosse o teatro e o drama de meu deitar não existia mais para mim, quando num dia de inverno, chegando eu em casa, minha mãe, vendo-me com frio, propôs que tomasse, contra meus hábitos, um pouco de chá(...). E logo, maquinalmente, acabrunhado pelo dia tristonho e a perspectiva de um dia seguinte igualmente sombrio, levei à boca uma colherada de chá onde deixara amolecer um pedaço de madeleine(...). E de súbito a lembrança me apareceu. Aquele gosto era o do pedacinho de madeleine que minha tia Léonie me dava aos domingos pela manhã em Combray(...). A vista do pequeno biscoito não me recordara coisa alguma antes que o tivesse provado(...); talvez porque, dessas lembranças abandonadas há tanto fora da memória, nada sobrevivesse, tudo se houvesse desagregado(...). E logo que reconheci o gosto do pedaço da madeleine mergulhado no chá que me dava minha tia(...), logo a velha casa cinzenta que dava para a rua, onde está o quarto dela veio como um cenário de teatro se colar ao pequeno pavilhão(...), assim agora todas as flores do nosso jardim e as do parque do Sr. Swan, e as ninféias do Vivone, e a boa gente da aldeia e suas pequenas residências, e a igreja, e toda Combray e suas redondezas, tudo isso que toma forma e solidez, saiu, cidade e jardins, de minha xícara de chá (PROUST, 1992, p. 55-58).

Esta longa citação estabelece a importância que os lugares vividos e imaginados acabam tendo na configuração da memória de referência individual. São as diversas 
sensações experimentadas as produtoras de uma dada configuração das coisas e dos fenômenos, sensações que ficam armazenadas em nossa memória e quando estimuladas, das formas mais diversas, trazem à tona as antigas experiências vivenciadas. Essa memória, que não é fruto de um exercício intelectual em si, permite entender a vida como uma obra de arte, como um fenômeno criado por cada um de nós a partir das lembranças, boas ou ruins, de maneira a dar sentido mais profundo e original à nossa existência, permitindo que, por meio dessa tomada de decisão, a vida seja produzida como algo que vise a completude humana e não a sua cômoda alienação e derrocada.

De uma simples xícara de chá todo um tempo e espaço aparecem como por encanto, como por um milagre só realizado pela capacidade humana de sentir e pensar o mundo. De um ponto ínfimo do lugar que hoje habitamos, conseguimos resgatar um outro lugar, que pode ser o mesmo, mas com outra vida, com outras experimentações, sabores, nomes, sonhos e frustrações. Em nossa mente, nomes e imagens tomam forma e solidez, graças a nossa capacidade de captar e interagir a forma e os nomes das coisas percebidas, conscientemente ou não, com o sentido de vida que damos às mesmas.

Os nomes poderiam ser apenas signos vazios; as formas poderiam ser apenas aparências ocas, cascas frágeis dos objetos; os lugares poderiam ser apenas pontos de referências em planos abstratos, delimitados por coordenadas numéricas em si; a vida poderia ser apenas trabalhar, comer e dormir, numa rotina estúpida de dor e desilusão, assim como as pessoas poderiam apenas ser um número estatístico ou do registro presente nas carteiras de identidade. Mas graças à nossa memória, à nossa capacidade de dar sentido humano para esses fenômenos todos, os nomes interrelacionam-se com lugares e pessoas, fazendo da forma como os percebemos um todo conteudístico que enriquece e se diversifica em significados, fazendo da vida não apenas um vazio estúpido e amorfo, mas também alegria e criação.

Nesse sentido a vida é possível de ser entendida como uma obra de arte, pois não se restringe a uma idéia de belas artes em si, a algo que se fundamente apenas ao que é harmonioso e agradável, mas porque está em relação direta com a sua negação, com outros elementos que não se incluem no meramente prazeroso. A vida é vida porque está em relação com a morte, assim como a infância está em contato direto com a velhice, o sono com o despertar, a fantasia com a razão e, sendo assim, viver é um constante recriar, relembrar, reviver o passado em novas situações, fazendo que o vivido não se petrifique em alguma suposta verdade de fatos inquestionáveis, mas num constante recriar dos sentidos desses fatos e fenômenos, mudando-os, refazendo-os. 
Essa capacidade altamente artística que a memória tem de recriar e reinventar o passado conforme as condições do presente, como Proust apresenta em sua obra, advém em grande parte do fato de não se entender os fenômenos da vida como meras categorias mecanicamente duais em si, como, por exemplo, a relação trabalhada pelo escritor do sono com o despertar. Logicamente que entre sono e despertar se estabelece uma estreita relação, mas entre ambos e com ambos ocorre uma série de outros elementos e fases que diversificam e dão outros sentidos a cada uma das partes na própria relação estabelecida. Assim também temos entre o homem e a mulher, como em Sodoma e Gomorra, a homossexualidade masculina e a feminina, para não falar em bissexualidade e em ausência de sexualidade etc., torna mais complexa esta questão dos dois gêneros sexuais idealizados pela sociedade ${ }^{3}$; a obra de Proust se desdobra numa crítica a essa dualidade de oposições, entendendo mais como uma necessidade de simplificar e fixar nosso entendimento sobre a complexa multiplicidade dinâmica da vida do que a representação verdadeira e inquestionável da realidade.

Em Proust, um elemento, força ou fenômeno coloca-se contrário a outro mais no sentido de suas interdependências, de um depender e gerar mutuamente os seus outros possíveis e impossíveis, como o personagem paulatinamente se dá conta conforme a questão da sexualidade vai sendo expressa por múltiplos sentidos por meio dos vários personagens ao longo da narrativa.

Assim, por entre as séries de descrições de detalhes cotidianos vivenciados por seu personagem central, Proust, em seu livro, vai demonstrando como os atos simples, os pequenos objetos, os gestos banais do dia-a-dia, na verdade expressam e sedimentam a vida em sua riqueza e dinâmica. Como da xícara de chá veio toda uma vida em turbilhão, interagindo tempos e espaços diferentes graças a memória humana, o mesmo ocorre em cada gesto da vida, que interage e integra toda a riqueza e a beleza que é viver. Neste sentido, a vida é uma obra de arte, pois em cada pequeno detalhe se está

\footnotetext{
${ }^{3}$ Um exemplo claro dessa diversidade de sentidos que é a vida enquanto obra de arte, a qual Proust tenta captar/expressar por meio de seus personagens, pode ser encontrado na questão da sexualidade imbricada com o amor. Proust coloca isso por meio do narrador no romance, quando esse constata o fato de ficar triste toda vez que começava a amar alguém, pois sabia que um dia toda aquela emoção iria acabar, trocando a felicidade por dores incomensuráveis e ciúme. No trabalho de Nicolas Grimaldi: O Ciúme um estudo sobre o imaginário proustiano, o pesquisador demonstra como um sentimento/conceito na obra de Marcel Proust acaba tomando uma diversidade de formas e sentidos, como se expressasse a presença do mesmo na vida cotidiana de qualquer ser humano. "Tão polimorfo seria, pois, o ciúme que é ora a precisão, ora a imprecisão que tornariam a sua imaginação intensa e dolorosa, ora por saber, ora por ignorar, ora a obsedante determinação do concreto, ora a vertiginosa indeterminação do possível. Tantas são as naturezas no homem" (1994, p. 50).
} 
construindo e criando algo eterno, ou seja, a nossa própria humanidade enquanto imaginação humana.

\section{A QUESTÃO DA VERDADE: DA IMPOSSIBILIDADE DE SE DEFINIR TOTALMENTE O OUTRO}

Nelly Stéphane, em seu artigo A Escrita, analisando a elaboração do livro de Proust, aponta que este tenta expressar em sua obra não a realidade nua e crua, mas sim como a imaginação humana faz dessa realidade uma verdadeira obra de arte, recriando, pela linguagem e pela imaginação, os fatos, interagindo-os, recriando-os, diversificando os sentidos, tornando-os humanos, passíveis de serem vividos.

[...] inutilmente se tentará demonstrar que, para Proust, a identidade de um lugar, de um personagem, o que se designa pelo nome, está sempre ligada a múltiplas aparições que, talvez se contradigam mas com maior certeza se encaixam, se encadeiam umas às outras - o lugar muda de aspecto, o personagem de idade, de sexo, de fisionomia, de personalidade [...] - serão inúteis todas essas tentativas se não se percebe, de saída, que essas metamorfoses não se passam na realidade e sim no pensamento, ou, mais precisamente, na linguagem [...] - não se trata de um personagem mas de uma constelação, não de uma história mas da vida mesmo, de fazer com que percebamos as coisas e o seres não como tenham sido na realidade, mas como imaginação os captou (STÉPHANE, 1971, p. 229).

Para Proust, a vida é uma arte, pois a forma como a interpretamos sofre influência de nossos desejos, fantasias, imaginação, além das características limitantes de nossos sentidos e da incrível capacidade de nossa mente em recriar a lógica dos fenômenos. A realidade, portanto, acaba sendo a recriação de sentido que damos à mesma e não aos seus elementos em si. Ao humanizarmos esses elementos os mesmos são recriados pela ação e intelecto humanos, fazendo do real algo recriado pela nossa imaginação, ou seja, passível de ser vivido, apesar de todos os dissabores e desilusões que permeiam a existência dos homens individualmente e em grupo. Por isso, na citação anterior a autora coloca que em Proust não se trata de "história mas da vida mesmo", ou seja, que a própria vida humana é assim, não é a crueza da realidade em si, mas que o real é a vida conforme a "imaginação o captou”, portanto, é uma verdadeira obra de arte.

Poder-se-ia deduzir daí que tanto a vida quanto a arte são mentiras que elaboramos para não enfrentarmos a realidade, mas este seria um erro e simplificação da análise. Seria como reduzir tudo a uma anteposição entre um caminho certo e um caminho errado, ou uma forma verdadeira de se interpretar o mundo como superior a 
uma forma mentirosa, que nos engana. No entanto, não existe verdade sem sua intrínseca relação com a mentira e, mais que isso, não existe só uma verdade como não existe só uma mentira para cada coisa e fenômeno no mundo. Viver é um constante reavaliar das verdades e mentiras, que acabam se sobrepondo e construindo outras verdades e mentiras, sempre relativas e mutáveis. Leda Tenório, em seu artigo As Amantes Proustianas, observa corretamente que o próprio estilo de redação de Proust aponta para a impossibilidade de uma verdade localizada numa afirmação única e precisa.

Mais prudente seria pensarmos que Proust não está verificando nada ao afinar assim sua escrita, levando-a, via redução, a uma ponta aguda. E isso não só porque as conclusões proustianas são sempre provisórias, e altamente revogáveis, mas sobretudo porque é o próprio escritor quem nos adverte sobre a precariedade de toda bela formulação, da fragilidade dos ditos, ao tomar nota, em seu projeto de romance, de que "boa parte do que dizemos não é senão uma recitação" (TENÓRIO, 1995, p. 442).

Esse caso é exemplificado no livro quando aborda o amor do narrador por Albertine, uma das personagens principais de Em Busca do Tempo Perdido, tanto que dois livros da série se relacionam diretamente a ela, o volume 5 (A Prisioneira) e o volume 6 (A Fugitiva). Tais volumes abordam o amadurecimento de Marcel com a dor do amor não correspondido, com a conscientização dos atos absurdos que toma movido pelo ciúme, checando seus princípios e idealizações morais, e o ter que conviver com a perda do objeto amado, a princípio pela fuga de Albertine de sua casa e depois pela morte da mesma. Essas experiências todas trará amadurecimento ao personagem à custa de muita dor e desilusão, levando-o a ter que mudar seus valores e perspectivas pessoais relacionadas a si mesmo, ao relacionamento humano e ao sentido da vida. Numa bela passagem de A Fugitiva ele pensa sobre essas mudanças da seguinte forma:

Eu teria sido incapaz de ressuscitar Albertine porque era incapaz de ressuscitar a mim mesmo, de ressuscitar o meu eu de antigamente. A vida, segundo seu hábito, que consiste em trabalhos incessantes e infinitamente pequenos para mudar a face da terra, não me dissera no dia seguinte à morte de Albertine: "És outra pessoa", mas, através de mudanças demasiado imperceptíveis para que eu me desse conta dessa mesma mudança, renovara quase tudo em mim, de modo que meu pensamento já estava habituado a seu novo senhor [...]. A morte age da mesma forma que a ausência. O monstro a cuja aparição o meu amor estremecera - o esquecimento - de fato, com eu imaginava, acabara por devorá-lo (1995a, p. 220).

Dos primeiros contatos que o narrador teve quando jovem com Albertine, de uma sensação de distância em relação àquela moça que andava em grupo, brincando 
com outras moçoilas, escutando suas conversas, capitando então uma postura de independência esnobe, passando pelas primeiras palavras trocadas e toda a sensualidade e pureza identificada na mesma, em comparação com o desenvolvimento do amor, a desconfiança do grupo de moças e do rol de amizades desenvolvido por Albertine, no qual a libertinagem e a dubiedade sexual eram a tônica, fazendo com que Marcel chegasse ao extremo de levá-la para sua casa e deixá-la praticamente presa, constantemente vigiada, mas sempre desconfiado das visitas que recebia e dos passeios que realizava, desenvolve-se todo o percurso que consolida a história amorosa dos dois personagens.

De informações que tinha do passado dessas relações, sempre imprecisas e comprometedoras, aumentava a desconfiança do personagem principal em relação a sua amada, ao mesmo tempo em que mais buscava uma verdade definitiva, mas só encontrava suspeitas e dúvidas. Nesse mundo de aparências e mentiras é onde construiu seu amor, também elaborando mentiras na tentativa de conseguir uma confissão da moça em relação ao seu passado e de sua traição, até o dia em que ela foi embora não agüentando tanto sofrimento, e este fato tornou-se ainda mais trágico quando, algum tempo depois, o personagem recebe a notícia de que a mesma havia morrido. E assim o ciclo, que na verdade é espiralado, completa seu movimento que nunca acaba, retomado sempre a uma nova situação quando percebe o tempo trazendo o esquecimento do amor que sentia em relação a Albertine.

Nessa relação de amor, a princípio tão intensa e pura, mas que foi se desdobrando em situações mais complexas e paradoxais, levando ao estranhamento do personagem ao que projeta de sua amada, e de si mesmo, vê-se que ao final, a doce e simples Albertine se caracterizou por um conjunto diverso de imagens e percepções. Qual era a verdadeira? Assim como ele próprio foi amadurecendo e mudando, apesar de ser sempre o mesmo Ser, o mesmo ocorreu com Albertine e, como ocorre a todos nós, talvez aí resida o fato dele ter várias impressões da moça, pois esta expressava a diversidade de comportamentos e valores presentes em todas as meninas em flor, mesmo que muitas daquelas noções, com o tempo, já não ocorressem mais, mas haviam sido depositadas na personalidade da mesma, esculpindo-a, repercutindo na direção de seus valores, pensamentos e atos presentes e futuros.

Marcel acaba por perceber que buscar uma definição estabelecedora da verdade sobre uma pessoa é um erro, pois as pessoas são fruto dessa diversidade de erros e acertos, de coisas boas e ruins, que, conforme o contexto, é percebida de forma 
diferenciada pelas pessoas com as quais se relaciona. Num outro trecho de $\mathbf{A}$ Prisioneira, Marcel, com raiva e ciúme de um dos amigos de Albertine, o senhor Verdurin, ouve de um amigo o relato de ajuda financeira que Verdurin insistiu em fazer para um conhecido que falira economicamente. Após relato confidencial, pois Verdurin não queria alardes sobre o mesmo, Marcel reflete sobre como odiava aquele homem que trazia tantas dúvidas em relação à fidelidade e a sexualidade de Albertine. Acaba concluindo o seguinte:

Em primeiro lugar, isso me teria levado mais rapidamente à ideia de que jamais é preciso querer mal aos homens, jamais se deve julgá-los conforme a recordação de uma maldade, pois não sabemos tudo o que, em outros momentos, pôde a alma deles querer sinceramente realizar de bom [...]. Todavia, no momento da minha descoberta, a natureza do Sr. Verdurin me apresentou uma nova face insuspeitada; e daí concluí a dificuldade de apresentar uma imagem fixa tanto de um caráter como das sociedades e das paixões (1994b, p. 297-298).

Nota-se, assim, que em Proust o sentido de uma verdade fixa é impossível, esta acaba sendo a interação de vários aspectos, faces, atos e perspectivas que cada indivíduo, em sua diversidade de posturas, elabora ao se relacionar com o mundo. Mas, dando sequiência ao exemplo do amor do personagem central por Albertine, percebe-se a tomada de consciência, por parte do narrador, de que Albertine não cabia em uma só descrição ou conceituação, de que ela era essa complexidade de comportamento e valores e que ele, enquanto viveu com ela, buscou reduzi-la a uma uniformidade representativa e idealizada, inviabilizando se relacionar com ela enquanto multiplicidade diferencializante e complexa.

Quando percebe que Albertine é uma multiplicidade, compreende que muitas dessas noções e dúvidas podiam ser mentiras, interpretações errôneas e até maldosas de determinadas pessoas, até dele mesmo, no entanto, essa série de erros e mentiras confluíam para formar a verdadeira Albertine, chegando ao ponto em que, quando se recordava dela, pensava em ângulos do seu ser dos quais gostava, mas estes estavam amarrados com os demais, realçando os mesmos ou dando um colorido diferente conforme o contexto da recordação.

Ao projetar essa análise sobre a relação, percebeu que aquilo que identificava como amor, na verdade era a interação de vários sentimentos intrinsicamente amalgamados, como ódio, insegurança, o ciúme, até o endeusamento e supervalorização da beleza da amada. Percebeu, então, que a série de dúvidas e mentiras que ocorreram permitiu a produção de uma aparência de casal, que acabava por ser a verdadeira 
essência da relação entre ambos, ou como o próprio narrador afirma: "Aliás, nessas mentiras, sentimos muito bem o que existe de verdade, sentimos que, se a vida não traz. mudanças em nossos amores, nós mesmos é que nos encarregamos de causá-las ou fingi-las" (1994b, p. 321).

Não podia pensar, depois de tanto tempo, na verdade essencial daquele relacionamento sem todas as mentiras e dúvidas produzidas. Não podia buscar uma essência que não fosse aquela aparência com a qual registrou e demarcou o relacionamento; aquela forma que a memória apreendeu e resgatava toda vez quando sentia saudades ou lembranças. Verdade e mentira, aparência e essência acabavam por interagirem entre si e produzirem um quadro a revelar e esconder as coisas; assim se forma a memória humana como força potencializadora a recriar os fatos, tornando-os passíveis de recordação, demarcando nossa existência futura.

Em Proust, os fatos nunca aconteceram exatamente da forma como foram entendidos, e por nunca acontecerem exatamente assim é que eles acabaram transformando-se naquilo que se interpretou sobre como eles de fato aconteceram. A imaginação humana recria aos mesmos, e graças a esta recriação é que um determinado fato ou fenômeno em sua manifestação crua pode ser entendido por uma variedade de ângulos e aspectos e, assim sendo, a vida torna-se diversa, dinâmica e desafiante, advindo daí a riqueza de contradições e interpretações. Caso reduzíssemos todos os fatos, elementos e fenômenos à crueza pura em si em que se manifestam, tomando a isto como a única verdade essencial da realidade, o mundo se empobreceria, tornando-se então feio e triste. A beleza vem da diversidade de possibilidades, de perspectivas e de leituras outras, o que incita à criação e à recriação.

Quando reduzimos essa diversidade a apenas um ângulo, tomando este como a verdade única e essencial, acabamos por nos tornar pessoas limitadas e limitantes, pois empobrecemos o mundo em nome de uma verdade isolada dos demais aspectos que fazem da vida a própria potencialidade de consolidação da existência humana. Esse vício racionalista que insistimos em perpetuar, tanto na ciência quanto na mentalidade mundana, é que fez o personagem buscar uma verdade essencial para definir de forma absoluta Albertine, sendo esta busca aquilo que o torturava e não permitia viver a vida de forma mais ampla, mas reduzia esta aos sofrimentos e angústias perpetrados pela busca da verdade definitiva sobre quem era realmente o seu amor.

Quando se abre para o mundo e percebe que as coisas e os seres humanos não são passíveis de mera simplificação, de uma definição conceitualmente precisa em sua 
essencialidade absoluta, mas que a compreensão destes só é possível no entendimento do sentido artístico da vida, percebendo como são passíveis de várias leituras porque são eles próprios diversos, contraditórios e dinâmicos, é que o personagem consegue tornar mais suportável sua existência. Essa compreensão identifica-se em uma passagem do O Tempo Recuperado, sétimo e último volume do seu livro clássico:

Ora, a recriação, pela memória, de impressões que a seguir era necessário aprofundar e esclarecer, transformar em equivalentes da inteligência, não seria esta uma das condições - quase a essência mesma - da obra de arte tal como concebera há pouco na biblioteca?

E responde a isso com o exemplo da morte.

Se a noção da morte, naquele tempo, me entristecera o amor, como vimos, fazia já tempos que a recordação do amor me auxiliava a não temer a morte. Pois compreendia que morrer não era nenhuma novidade(...). Essas mortes sucessivas, tão temidas pelo 'eu' que deveriam aniquilar, tão indiferentes, tão suaves uma vez cumpridas, e quando aquele que as temia já não estava ali para senti-las, tinham-me feito desde algum tempo compreender quão pouco sensato seria aterrorizar-me com a morte $(1995, \text { p. } 342)^{4}$.

Ao assim se posicionar, Proust estabelece uma estreita relação entre obra de arte e vida, justamente no seu fim, isto é, em sua morte. Encontra-se, a partir deste exemplo, a possibilidade de construir sentidos mais amplos e profundos, de produzir espacialmente a beleza do mundo na sua interação com a existência humana, como ele escreve em A Prisioneira sobre a interação imagética entre as pinturas do pintor holandês Vermeer e os escritos do russo Dostoievski.

Você me disse que tinha visto certos quadros de Vermeer; notou bem que são fragmentos de um mesmo mundo, que é sempre, seja qual for o gênio com que foram recriadas, a mesma mesa, a mesma toalha, a mesma mulher, a mesma nova e única beleza [...], assim como em Vermeer existe a criação de uma certa alma, de uma certa cor de tecidos e de lugares). Essa beleza nova e terrível de uma casa, essa beleza nova e mista de um rosto de mulher, eis o que Dostoievski trouxe de único ao mundo (1994, p. 344-345).

Essa interação entre artes pictóricas e literárias expressa o fundamenta da criação das mesmas no próprio fluir da vida humana, sempre a se repetir, mas de maneira diferente, como a memória faz com os fatos recordados, instaurando outros sentidos para o vivenciado, fazendo a vida acontecer com outras potencialiadades

\footnotetext{
${ }^{4}$ Vemos assim que a obra, como a vida, deve ser um caminhar para a morte, mas sem medo, como uma forma de esgotar todos os sofrimentos, de forma que nosso ser, tanto corporal quanto intelectual, bem como nossas alegrias e tristezas adubem o solo da vida das novas gerações, de modo que o espaço por nós habitado e experimentado gere um solo fértil para os novos tempos, para que os homens possam almoçar sobre o mesmo, como simboliza o quadro de Éduard Manet, citado por Proust (1992, p. 230), Almoço Sobre a Relva.
} 
criativas, com novas belezas, mesmo que doloridas. Uma espacialidade assim entendida/vivida nunca se esgota numa verdade definitiva, num tempo linear, na crueza essencialista dos fenômenos em si.

\section{PALAVRAS FINAIS: VOLTANDO À GEOGRAFIA E A QUESTÃO DA PAISAGEM}

As observações apontadas no final do último item deste artigo permite abrir para uma alegação sobre essa capacidade humana de recriar os fatos observados e experimentados referir-se mais a posturas presentes no cotidiano humano de indivíduos ou grupos específicos, não garantindo uma leitura que seja pertinente ao entendimento do mundo em sua realidade, logo, insere-se mais numa postura de criação artística, de produção de significados diversos e não compromissados com a verdade objetiva do conhecimento, como é o científico.

Diante de uma possível crítica como esta, aqui se volta a insistir, a partir da obra de Marcel Proust, sobre a questão da verdade não ser exclusivista, restrita a apenas um aspecto, mas que ela está na diversidade do mundo, portanto, se a análise de Proust se presta mais a uma concepção de arte, esta concepção pode contribuir para a ciência estabelecer a autocrítica no sentido de não acreditar cegamente numa verdade fixa e absoluta das coisas, mas tentar entender a produção desta como o homem produz sua existência. Nesse ponto o romance de Proust nos instrui, pois apresenta essa vida como uma obra em constante interação e recriação dos fatos e experiências pela imaginação e pela memória, tal aspecto acaba por determinar os sentidos e interpretações dos mesmos, fazendo da verdade algo possível dentro de determinado contexto.

É claro que o objetivo da arte é diferente do da ciência, mas esta não pode descartar a contribuição de Proust, no sentido de buscar entender a vida em seus aspectos mais rotineiros e cotidianos, ser de grande relevância para fazer da ciência não uma infalível construção intelectual a dizer como as coisas devam ser, mas que torne possível a elaboração de leituras e representações capazes parametrizar a compreensão espacial da existência humana frente às diversas possibilidades de leituras e interpretações dos fatos.

Esse é o sentido da observação de Proust, em seu texto Sobre a Leitura, em sua crítica aos limites da leitura moderna em tentar substituir o despertar para a vida por um comodismo do pensar, substituindo a criação artística e da verdade nunca absoluta por 
uma espécie de reprodução da utilidade científica de uma verdade já dada como inquestionável.

Na medida que a leitura é para nós a iniciadora cujas chaves mágicas abrem no fundo de nós mesmos a porta das moradas onde não saberíamos penetrar, seu papel na nossa vida é salutar. Torna-se perigosa, ao contrário, quando, em lugar de nos despertar para a vida pessoal do espírito, a leitura tende a substituir-se a ela, quando a verdade não aparece mais como um ideal que não podemos realizar senão pelo progresso íntimo de nosso pensamento e pelo esforço de nosso coração, mas como uma coisa material, depositada entre as folhas dos livros com um mel todo preparado pelos outros e que não temos senão de fazer o pequeno esforço para pegar nas prateleiras das bibliotecas (1991, p. 35-36).

Essa observação se aplica muito pertinentemente à geografia, principalmente pelo fato de que o romance de Proust trabalha com dois elementos que muito se interagem com o espaço: a) A memória - de nomes, lugares, paisagens e imagens; b) $\mathrm{O}$ tempo, que trabalha a partir dos lugares e espaços vividos ou imaginados pelo personagem central do romance. Ao assim desenvolver sua obra, as observações de Proust acabam contribuindo de forma instigante para essa interação entre conhecimento científico da geografia e arte, tomando como referência a sua leitura da vida enquanto obra de arte.

Ao observar o primeiro volume de seu Em Busca do Tempo Perdido, percebese como o relato de determinados lugares produziram uma dada paisagem, fruto da reelaboração de imagens mentais do personagem central da obra. Ao analisar o caso Balbec, vê-se que a elaboração de uma determinada região assim denominada se deu após leituras que fez sobre outras instâncias praianas, relacionando essas com romances de aventuras marítimas, interagindo esse textos com desenhos, pinturas e descrições de lugares e experiências que pessoas mais velhas passaram na referida Balbec; diante desse arsenal de referências, o jovem Marcel elabora uma paisagem fantasiosa, fruto de seu imaginário íntimo, sem a experiência concreta com o referido local.

Mais tarde, quando de fato vai a Balbec, compara o que imaginara com o que estava vivenciando e se decepciona. Caminhado pelos arredores, conversando com pessoas, experimentando as diversas faces e detalhes do lugar, acaba por reconstruir um referencial do mesmo. Esse referencial fica arraigado em sua memória durante muito tempo, servindo de base para suas recordações de nomes, pessoas e partes de Balbec que davam uma noção do que era esta localidade, sua geografia e história, a partir dos contatos estabelecidos enquanto ainda era jovem. 
Ao ficar mais velho, retorna a Balbec e percebe que a imagem desta por ele construída após sua primeira vinda não era a mesma que agora experimentava. Ele e o lugar pareciam diferentes, apesar de ainda serem os mesmos. Decepcionara-se, como antes, ao comparar a paisagem em sua memória com aquela que estava vendo e vivenciando, no entanto, outras experiências o aguardavam nessa Balbec de sua vida adulta, o que acarretaria novas informações do lugar, que seriam recriadas pelos sentidos e imaginação, produzindo uma nova paisagem que a memória elaboraria e que nunca seria possível de definir a Balbec essencial e inquestionável, pois essa era a forma possível de viver e trocar experiências com o local. Era assim que o lugar tornava-se real, via recriação do mesmo pela memória humana.

As indicações que Legrandin e Swann dão ao Narrador fazem nascer nele um Balbec espiritual caracterizado por uma forte tipificação [...]. Esta paisagem imaginária se manifesta quando existe uma analogia entre ela e a sensação presente [...]. O Balbec da lembrança vai se encarnar durante a segunda estada. Segunda decepção: a paisagem da memória, mesmo quando teve origem na paisagem real, é uma paisagem espiritual que, do mesmo modo que a paisagem da imaginação, não poderia ser o puro reflexo da realidade material. Estamos em presença de um mecanismo sem fim: toda paisagem espiritual tende a se encarnar, toda encarnação é decepcionante e segrega uma nova paisagem espiritual (NICOLAS, 1971, p. 100-101).

Vê-se assim que os lugares só se tornam lugares quando vivenciados. Essa vivência pode ocorrer imaginariamente, via relatos e representações feitas por outros, ou por fotos e pinturas, ou por meros nomes que nos atraem; mas essa vivência se dá de maneira mais intensa quando diretamente experimentam-se os lugares, as pessoas e os nomes que aí estabelecem relações e sentidos.

Desta forma é que criamos uma dada paisagem mental, a qual será uma paisagem recriada pelo imaginário humano que valoriza determinados aspectos, fruto de nossas sensações e impressões, de nossa capacidade de mentalmente destacar certos detalhes, cores, cheiros e demais sensações, comparando e relacionando com o que já tínhamos de referência sobre as mesmas. Essa paisagem nunca será a expressão crua e objetivamente precisa da realidade física do território ou objeto em si, mas sim uma recriação; nesse ponto, a realidade da paisagem acaba sendo essa relação de distância e proximidade que existe entre o real em si e aquilo que elaboramos de significado e sentido sobre o mesmo.

Em Proust, a paisagem incorporada pela mente, a partir do nosso imaginário e vivência, sempre acarretará a decepção quando comparada com a paisagem real em si; 
no entanto, esse é "um mecanismo sem fim", ou seja, toda comparação do que temos em mente com o real é decepcionante, mas a partir disso recriamos essas imagens e elementos em si, meras entidades enclausuradas em sua fundamentação física, elaborando paisagens, expressando os sentidos espaciais com os quais entendemos nossa existência.

Através de seu personagem principal apresenta-nos esse processo, como no caso em que observa os quadros pintados por Elstir, que tratam da paisagem de Balbec. Elstir é um pintor criado por Proust com tendências impressionistas, ele pinta paisagens do referido balneário, mas não como se fosse uma fotografia exata e cartográfica de Balbec. Seus quadros são brilhantes, sem formas definidas, com imagens espiritualizadas das paisagens, no entanto, são Balbec. O narrador destaca determinados aspectos da mesma que ficaram no imaginário do pintor e, quando comparadas com a Balbec real em si, provocam intrigas porque o registrado na pintura não é exatamente o mesmo mundo tomado em sua essência real, no entanto, é a Balbec, só que recriada, iluminada e dando um sentido humano e de vida para este.

A paisagem, assim como o mundo em sua essência nua e crua, completa-se quando recriada pelo imaginário, enriquece-se, amplia-se; torna-se realidade em seu sentido mais amplo e belo. François-Xavier Nicolas esclarece melhor essa questão da paisagem enquanto arte na vida em Proust.

O "enquadramento" da paisagem de Balbec [...] não revela um gosto pervertido pela visão indireta, mas um encaminhamento para a arte [...]. A arte é o instrumento que nos permite traduzir nossas impressões subjetivas e comunicá-las aos outros (transformando-as em elementos intelectuais assimiláveis por todos); reprodução de um universo subjetivo é, de certo modo, a objetivação de uma subjetividade[...]: a visão proustiana se situa no nível em que a arte e a vida se enriquecem e se afinam mutuamente, pelo intercâmbio de conhecimento que passa de uma à outra [...]. A natureza 'tal como em si mesma' que se dá na sensação e a natureza espiritualizada que a arte nos apresenta se unem e se completam (1971, p. 104-105).

A paisagem assim enfocada passa a ser tomada como uma obra de arte, pois é fruto também dos limites e da capacidade da mente humana de recriar seu sentido, tornando-a rica e diversa, ou seja, ao resgatar a mentira e o grotesco da mesma, realça as verdades e a beleza dos lugares em que se estabelece o viver humano.

Mas a paisagem dos espaços em Proust tem uma conotação ainda mais humana. Ao identificar que o real só o é de fato quando transformado pelo imaginário humano, Proust qualifica aí o sentido de paisagem para a geografia. Paisagem, portanto, só pode 
ser entendida enquanto fenômeno intrinsecamente relacionado com o imaginário humano, o que faz da mesma não apenas uma relação de coisas e nomes em determinado lugar, mas a capacidade de humanização dessas coisas e nomes - de nossa capacidade de tocar a tudo com nossas ações e sentimentos, de produzir amor, ódio, inveja, mentiras, verdades, ciúme, compaixão, tristeza, dor, alegria etc. - capacidade esta a permitir que, ao estabelecermos contato com alguns desses nomes e objetos em outro tempo e espaço, venhamos a resgatar dada paisagem que a memória guardou enquanto imagens desconexas, e passam assim a tomarem outros sentidos, não se restringindo à certa lógica exclusiva à razão conceitual pura, mas passível de entendimento humano.

François-Xavier Nicola esclarece melhor isso quando, no mesmo artigo, analisa que, a partir do momento no qual o Narrador passou a amar as flores, o mar e as moças de Balbec, esses elementos isolados em imagens passaram a ter sentido humano para o mesmo, elaborando uma paisagem passível de ser resgatada pela memória toda vez que tivesse contato com algum deles. Referindo-se ao caso mais específico da mulher em Balbec, ele explica:

O Narrador descobre, sem demora, além de uma simples relação de coexistência, analogias entre a paisagem de Balbec e as moças, dotadas da vida coletiva dos zoófitas, da incessante mobilidade do mar e às quais pode estudar com uma 'satisfação de botânico', que supõe certa ausência de paixão; mas quando ama nos faz observar que essas flores são "únicas, concretas e voluntárias". A jovem vendedora de leite é o produto natural e necessário de um solo de que reflete a essência material e que também transforma em elementos espirituais: ela é uma condensação espiritual da paisagem; conjuntamente a paisagem é a expressão da mulher, a encarnação de sua essência espiritual. A mulher e a paisagem se atraem e se identificam, de modo que a assimilação de uma se faz através da assimilação da outra (NICOLA, 1971, p. 101).

O Narrador iludia-se com a idéia de que poderia estudar friamente os elementos da paisagem de Balbec, no entanto, sendo humano, teria de se expressar humanamente, logo, começa a se sentir afetado pelos elementos que compunham a referida paisagem, daí os sentimentos se territorializarem em sensações de amor. Ao se expressar humanamente, passa a recriar o sentido das partes da paisagem observada, interagindo "espiritualmente" - imaginariamente - os elementos materiais entre si, fazendo com que, no caso da moça, esta fosse a paisagem concentrada, "em conserva" no dizer do crítico. A partir dessa postura de Proust, Nicola conclui que: 
Essas relações multiformes entre a mulher e a natureza e o mecanismo das "paisagens espirituais" nos mostram que a paisagem não é somente um pedaço da natureza: começa por árvores, flores, o mar e se completa na nossa imaginação, na nossa lembrança, no nosso coração (Ibidem, p. 103).

Como no caso da mulher em Balbec, percebe-se que os elementos componentes de todo o quadro denominado Balbec passam a ser reconhecidos como uma certa paisagem concentrada que introduz a memória no resgate dos lugares imaginados e vivenciados, ou seja, do mero constatar e descrever os elementos físicos isolados em imagens em si para uma interação de sentimentos que agenciam e derivam de um elemento para o outro, interagindo-os pela capacidade imaginativa e afetiva do ser humano. Tal capacidade recria os sentidos dos mesmos pela sensibilidade e racionalidade humana, de forma a estabelecer certa unidade de compreensão, possibilitando serem entendidos como paisagens que demarcam a memória do narrador, de sua capacidade de se entender no mundo e de entender este próprio mundo, até então apresentado como um turbilhão de fragmentos de elementos desconectados e estranhos ao indivíduo.

Por isso o Narrador, quando está em Paris, ao entrar em contato com as flores, percebe vir a sua memória as flores de Balbec, com suas ondas, moças, cores, perfumes etc. A flor, assim como a moça, interagia com o espaço em seu conjunto, sendo portanto a própria paisagem mentalmente recriada. $\mathrm{O}$ mesmo ocorre em relação à madeleine mergulhada no chá, que resgatou a paisagem de sua casa quando criança; o próprio biscoito é a paisagem, pois permitiu ao personagem em questão viajar no tempo e no espaço, desvendando os elementos, nomes, fatos e fenômenos que compuseram o arranjo espacial de determinado lugar em determinado momento de sua vida.

É nessa direção que se entende aqui paisagem geográfica, em sua estreita relação artística com nossa capacidade de produzir sentido a partir de uma série de imagens desconexas, fragmentadas e reduzidas a detalhes em si. Proust ricamente expressou e precisou este aspecto que todos nós elaboramos em nosso dia-a-dia, em nosso cotidiano.

Abre-se, por conseguinte, um horizonte muito amplo de abordagem para o conceito geográfico de paisagem a partir do contato com essa obra literária, o que pressupõe novas perspectivas e análises, que atualmente tornam-se extremamente necessárias frente as condições em da vida se territorializa num arranjo espacial que se pauta num lógica complexa, fragmentada, volátil e espetacularizante. Proust torna-se assim uma leitura fundamental para os geógrafos. 


\section{REFERÊNCIAS}

ABRAHAM, Pierre. Proust ou Marcel; in: Marcel Proust - o homem / o escritor / a obra. $1^{a}$ ed. Rio de Janeiro: Civilização Brasileira, 1971, p. 1-6.

ACHÈRES, Victoria. A Pintura e o Cenário da Vida em Proust; in: Marcel Proust - o homem / o escritor / a obra. $1^{a}$ ed. Rio de Janeiro: Civilização Brasileira, 1971, p. 325332.

BENJAMIN, Walter. A Imagem de Proust; in: Obras Escolhidas, vol. I. $6^{\mathrm{a}}$ ed. São Paulo: Brasiliense, 1993, p. 36-49.

CITATI, Pietro. Proust. $1^{a}$ ed. São Paulo: Companhia das Letras, 1999, 338 p.

DELEUZE, Gilles. Proust e os signos. $2^{\mathrm{a}}$ ed. Rio de Janeiro: Forense Universitária, 2006, 173 p.

DUPEYRON, Georges. Proust e a Crítica; in: Marcel Proust - o homem / o escritor / a obra. $1^{\text {a }}$ ed. Rio de Janeiro: Civilização Brasileira, 1971, p. 340-346.

FOURNIER, Albert. Ao Lado de Proust; in: Marcel Proust - o homem / o escritor / a obra. $1^{\text {a }}$ ed. Rio de Janeiro: Civilização Brasileira, 1971, p. 347-373.

GAUBERT, Serge. A Conversa e a Escrita; in: Marcel Proust - o homem / o escritor / a obra. $1^{\text {a }}$ ed. Rio de Janeiro: Civilização Brasileira, 1971, p. 234-268.

GRIMALDI, Nicolas. O Ciúme - estudo sobre o imaginário proustiano. $1^{\text {a }}$ ed. São Paulo: Paz e Terra, 1994, 63 p.

POULET, Georges. O Espaço Proustiano. $1^{\mathrm{a}}$ ed. Rio de Janeiro; Imago, 1992, 145 p.

PROUST, Marcel. No Caminho de Swann. Em Busca do Tempo Perdido, vol. I. $1^{\text {a }}$ ed. São Paulo: Ediouro, 1992, 376 p.

PROUST, Marcel. À Sombra das Moças em Flor. Em Busca do Tempo Perdido, vol. II. $1^{\text {a }}$ ed. São Paulo: Ediouro, 1993a, 464 p.

PROUST, Marcel. O Caminho de Guermantes. Em Busca do Tempo Perdido, vol. III. $1^{a}$ ed. São Paulo: Ediouro, 1993b, 496 p.

PROUST, Marcel. Sodoma e Gomorra. Em Busca do Tempo Perdido, vol. IV. $1^{\text {a }}$ ed. São Paulo: Ediouro, 1994a, 443 p.

PROUST, Marcel. A Prisioneira. Em Busca do Tempo Perdido, vol. V. $1^{\text {a }}$ ed. São Paulo: Ediouro, 1994b, 380p.

PROUST, Marcel. A Fugitiva. Em Busca do Tempo Perdido, vol. VI. $1^{\text {a }}$ ed. São Paulo: Ediouro, 1995a, 270 p.

PROUST, Marcel. O Tempo Recuperado. Em Busca do Tempo Perdido, vol. VII. $1^{\text {a }}$ ed. São Paulo: Ediouro, 1995b, 352 p. 
PROUST, Marcel. Nas Trilhas da Crítica. $1^{\text {a }}$ ed. São Paulo: EDUSP/Imaginário, 1994, $137 \mathrm{p}$.

REYMONT, Charles-Henry. A Arte e a Vida; in: Marcel Proust - o homem / o escritor / a obra. $1^{a}$ ed. Rio de Janeiro: Civilização Brasileira, 1971, p. 115-127.

SANDRE, Yves. Por Uma Estética do Dia-a-Dia; in: Marcel Proust - o homem / o escritor / a obra. $1^{a}$ ed. Rio de Janeiro: Civilização Brasileira, 1971, p. 63-92.

SILVA, Franklin L. Bergson, Proust - tensões do tempo; in: NOVAES, Adauto (org.): Tempo e História. $1^{\mathrm{a}}$ ed. São Paulo: Companhia das Letras, 1992, p. 141-154.

STÉPHANE, Nelly. A Escrita; in: Marcel Proust - o homem / o escritor / a obra. Rio de Janeiro: $1^{a}$ ed. Civilização Brasileira, 1971, p. 219-233.

TENÓRIO, Leda. As Amantes Proustianas; in: NOVAES, Adauto (org.): O Desejo. $1^{\text {a }}$ ed. São Paulo: Companhia das Letras, 1990, p. 439-456.

VUARNET, Jean-Noël. Sob o Signo dos Hieróglifos; in: Marcel Proust - o homem / o escritor / a obra. $1^{\text {a }}$ ed. Rio de Janeiro: Civilização Brasileira, 1971, p. 320-324.

ZAGDANSKI, Stéphane. O Sexo de Proust. $1^{\text {a }}$ ed. Rio de Janeiro; Zahar, 1995, 96 p.

Recebido em 05/09/2017.

Aceito em 10/11/2017.

Publicado em 02/01/2018. 